Article Type: Research Paper

\title{
The Factors Affecting the Composite Stock Price Index (CSPI) of Indonesia Stock Exchange
}

\author{
Nano Prawoto* and Bagus Ardyan Putra
}

\section{OPEN}

\section{AFFILIATION:}

Universitas Muhammadiyah

Yogyakarta. Yogyakarta, Indonesia.

*CORRESPONDENCE:

nanopra@umy.ac.id

THIS ARTICLE IS AVALILABLE IN:

http://journal.umy.ac.id/index.php/esp

DOI: 10.18196/jesp.21.1.5032

\section{CITATION:}

Prawoto, N., \& Putra, B. A. (2020).

The Factors Affecting the

Composite Stock Price Index (CSPI)

of Indonesia Stock Exchange.

Jurnal Ekonomi \& Studi

Pembangunan, 21(1), 69-83.

\section{ARTICLE HISTORY}

Received:

13 January 2020

Reviewed:

5 April 2020

15 April 2020

Revised:

17 April 2020

25 April 2020

Accepted:

27 April 2020
Abstract: The study examines the influence of The Fed Rate, inflation, Dow Jones Index (DJI), exchange rate, and world oil price on the composite stock price index (CSPI) in Indonesia. The method used in this study was the Vector Error Correction Model (VECM). The research showed that the influence of inflation towards the composite stock price index was negative both in the short term and long term. The influence of the exchange rate towards the composite stock price index was positive both short term and long term. The impact of oil price towards composite stock price index was positive in the short term and long term. However, both the Dow Jones Index (DJI) and The Fed Rate had a negative effect on the composite stock price index. The results of this analysis can be used as a reference for investor and government policymaking.

Keywords: The Fed rate; Inflation; Stock price index; Exchange rate; World oil price.

JEL Classification: E43; E31; G15; F31; G31.

\section{Introduction}

The relation between the influence of Macroeconomic and capital market variables have become an interesting topic for researchers and academics. Research on the capital market has been carried out with a variety of concepts. It is inseparable from the role of the capital market as a means of liaising between investors and the government or companies when investing in a country's capital market.

The capital market is an indicator of the development of companies in a country, both developed and developing countries. Indonesia is one of the developing countries, which uses capital markets to support national development in order to improve equity, growth, and national economic stability aimed at improving people's welfare. Community participation in becoming investors through financial instruments is the aim of the government to contribute to national economic development.

The development of the capital market in Indonesia is quite significant, as shown in Figure 1. It is shown that in terms of market capitalization value, the Indonesian capital market grew significantly from the position of Rp1,989 trillion in 2007 to Rp7,052 trillion per 2017. Meanwhile, in the 


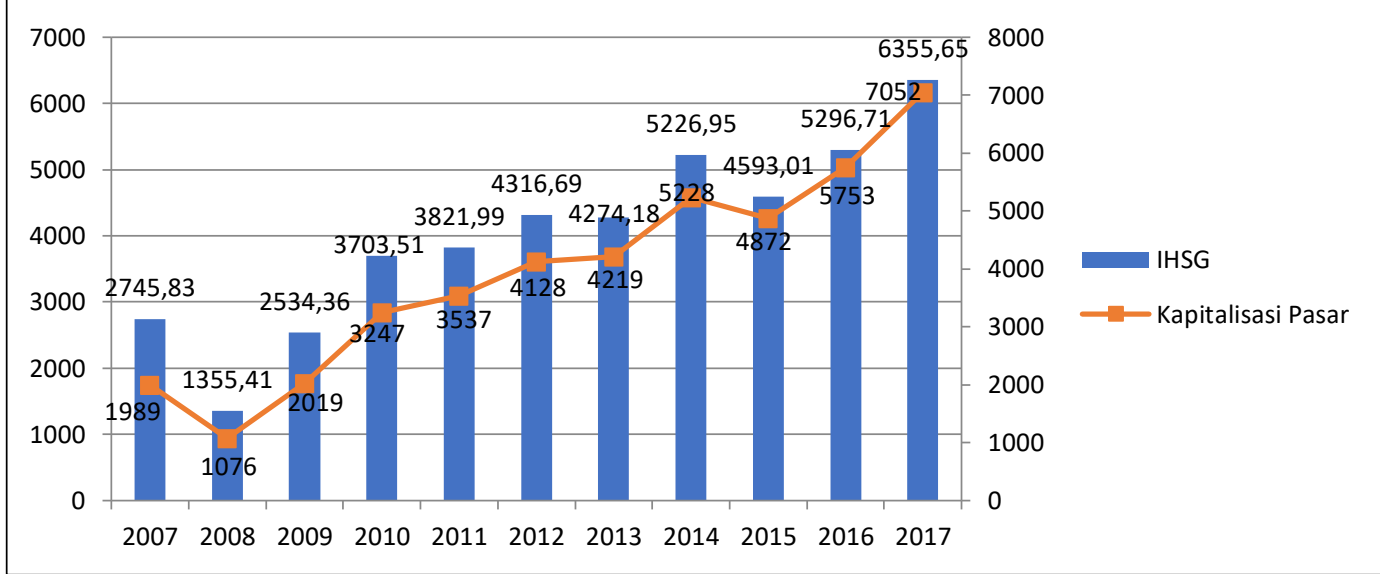

Figure 1 Composite Stock Price Index Chart (IHSG) Year 2007 - 2017

Source: IDX

same period, the Composite Stock Price Index (CSPI) grew 131.46 percent from 2,745.83 points in 2007 to 6,355.66 in 2017.

Various methods have been used by previous researchers in linking macroeconomic variables with the capital market. One of which was developed through the Arbitrage Pricing Theory (APT) approach (Ross, 1976). APT theory can explain the return of assets from several risk factors that occur, but the focus on APT is the rate of return of individuals from the stock market. In an aggregate stock market framework, any changes in certain macroeconomic variables can reflect future returns changes on the stock market. Empirical studies on APT theory mostly relate macroeconomic variables with the stock market by modeling their short-term relationship with stationary assumptions at the first difference.

The study by Nasseh and Strauss (2000) supports research on the stock market from the influence of macroeconomic variables. Johansen's cointegration approach demonstrates that in the long-run, stock prices are significantly related to industrial production, business surveys of manufacturing orders, long-term and short-term interest rates, and foreign share prices. Research with the cointegration approach is consistent with three thoughts. These three thoughts are: first, a stock market activity can determine long-term production. Second, the stock market has a very high level of volatility compared to the underlying macroeconomic variables. Third, economic activity explains more variations in stock prices over a long period. Based on the theory and intuition, activities on the capital market have a relationship with activities on macroeconomic variables directly through consumption and production activities. The rate of return from stocks can be the basis for estimating future production growth because production is related to other macroeconomic variables.

Another alternative approach is the Present Value Model (PVM). This model associates stock prices with expected cash flows and discount rates in the future. What needs to be considered in the PVM model is that all macroeconomic variables in the model must influence stock prices. Another advantage of applying the PVM model is the focus on the 
long-term relationship between stock market variables and macroeconomic variables. Campbell and Shiller (1988) estimated the relationship between stock prices, expected earnings, and dividends, while all variables are used in the moving average model in the long term.

Changes in individual stock prices are caused by demand and supply factors. Variables that affect demand and supply include company performance, inflation rates, interest rates, foreign exchange rates, growth rates, or stock price indexes from other countries. An increase in the Composite Stock Price Index (CSPI) does not mean that all types of shares have risen in price. The rise of CSPI indicates that some shares have increased while some others have declined. A type of stock is said to have a positive correlation if a type of stock rises in price when the CSPI expands, and vice versa. Knowledge of changes in market index prices or stock prices is essential to estimate the risk of a type of stock on market risk (Samsul, 2015). This study focuses on several questions: a) Is there any longterm relationship between macroeconomic variables and the stock market (in this case using the CSPI)? Also, b) What is the response of the stock market (CSPI) if there is turmoil in macroeconomic variables in the model?

This paper reinforces previous research in several sections, such as the effect of macroeconomic variables on the stock market in Indonesia and further study of how domestic macroeconomic variables can affect the stock market in Indonesia. This paper also has contributed to the literature on the use of international macroeconomic variables, namely the Fed rate. This variable is essential because Indonesia is a developing country, and external factors determine the sensitivity of the stock market. In addition to the Fed rate, the external variable also employs the variable of world oil price. This study would investigate the relationship between external and macroeconomic variables in the stock market toward Indonesia (IHSG) with a time-series data approach from 2013M1 2017 M12.

The portfolio theory, known as the Markowitz model, proposed by Markowitz (1952), is one way to get the return at the desired level with the minimum risk. In reducing or minimizing risk, it can be done in investing using diversification, by forming a portfolio or investing funds in several assets with a certain amount of funds. In-stock selection, it is necessary to observe by sector, after grouping the sectors, then selecting the issuers of shares to be invested. This selection is crucial because it must know the advantages of each sector so that it can estimate the price movement of shares (Samsul, 2015). Efficient capital markets are capital markets that explain the price of shares and can reflect existing information. Under these conditions, investors cannot profit from the sale of shares because every investor gets the same information. The capital market can be said to be efficient when information can be a picture of the price of the stock, which will make investors get the expected standard return. Information obtained by investors in advance will be meaningless because the price will automatically adjust to that information (Fama, 1970).

Ratanapakorn and Sharma (2007) applied the cointegration method and the Vector Error Correction Model (VECM) for monthly data in the US. Their research stated that there was 
a positive relationship between the money supply, industrial production, inflation, exchange rates, and short-term interest rates, but negatively related to long-term interest rates. The researcher also revealed that the US stock market was inefficient. Bhuiyan and Chowdhury (2019) used monthly data from 2000 - 2018 on US and Canadian stock market data. The data stated that there was a stable long-term relationship between macroeconomic variables (industrial production, money supply, long-term interest rates on sectors listed on the stock market) with the stock market in the US and Canada. Their research employed cointegration and VECM methods. In the study by Humpe and Macmillan (2009) on the US stock market, the consumer price index and long-term interest rates had a negative relationship. Still, industrial production and the money supply had a positive relationship where the money supply was not statistically significant. Stock markets in Japan had a negative correlation with the money supply and favorable to industrial production. The researcher also stated that the consumer price index was indirectly negatively related to stock prices caused by the effects of the industrial output.

As explained in the introduction, the researcher has constructed a model between macroeconomic variables and the stock market. Campbell and Ammer (1993) used the VAR model in its analysis and stated that there was a simultaneous interaction between the stock markets and bonds. In his research, it also indicated that interest rates were not the primary driver in determining the rate of return of shares. Previous researchers mentioned before used lag in the model. The use of lag in the model is to avoid spurious regression and data problems at the unit root. In addition to lag, some researchers applied cointegration methods to test economic theories, such as the present value model. The study by Campbell and Shiller (1988) examined the current value model that links the stock price $\mathrm{P}$, to Dividends, D:

$$
P_{t}=\sum_{i=1}^{\infty} \beta^{i} E_{t} D_{t+1}
$$

$\beta$ is the constant of the discount factor. By using Engle-Granger cointegration with lagged differences, then $\mathrm{HO}$, which states there is no cointegration can be rejected at the $10 \%$ at the level. The application of the lag and cointegration methods is essential to get consistent results (for time series data), avoiding spurious regression, and avoiding root unit problems in the data. Also, it is to explore further the sensitivity of the stock market in Indonesia and the factors that influence it from domestic and international macroeconomic variables and uses the latest data to examine post-crisis that occurred in 2007-2008.

\section{Research Method}

This study used monthly data for all dependent variables and independent variables. The data period used was from 2013: 01 to 2017: 12. The focus of the study was post-crisis in 2008. The independent variables used were domestic and international macroeconomic 
Table 1 Data and Data Source

\begin{tabular}{cll}
\hline No & \multicolumn{1}{c}{ Variables } & \multicolumn{1}{c}{ Source } \\
\hline 1. & Composite Stock Price Index (CSPI) & BEI Annual Statistics Report \\
2. & The Fed Rate & Federal Reserve Bank of St. Louis \\
3. & Inflation & Central Bureau of Statistics \\
4. & Index Dow Jones & Financial Services Authority \\
5. & Rupiah exchange rate against US Dollar & Bank Indonesia annual report \\
6. & World Oil Prices (West Texas Intermediate) & World Bank \\
\hline
\end{tabular}

Description: all data uses monthly data from 2013: 01 - 2017: 12.

variables. Furthermore, the international macroeconomic variables employed were the American interest rate (the Fed rate) and world oil prices. Domestic macroeconomic variables used inflation, exchange rate, and Dow Jones index variables. The dependent variable in this study utilized the Composite Stock Price Index (CSPI). CSPI is one of the indices used by the Indonesia Stock Exchange (BEI). This indicator covers all shares listed on the BEl.

Method

In this study, we used the Vector Error Correction Model (VECM) as an analytical tool. The stages that should be carried out in the VAR/VECM analysis were as follows (Basuki \& Prawoto, 2016).

\section{a. Stationarity Test}

The initial step in analyzing time series data was the stationarity test. Estimation of nonstationary time series data would cause inconsistencies in the results of regression or false regression. Time series data are generally stochastic (have non-stationary trends/these data have unit roots). If the data has a unit root, then the value will tend to fluctuate not around its average value, making it difficult to estimate the model. The method used to test the stationarity problem was the unit root test. The unit root test used the Augmented Dickey-Fuller (ADF) approach. The basic idea of a stationary test with a unit root test can be explained through the following model:

$$
\Delta Y_{t}=\propto+\delta t+\theta Y_{t-1}+\sum_{i=1}^{P} \lambda_{i} \Delta Y_{t-1}+\varepsilon_{t}
$$

$\Delta$ is difference operator, $\mathrm{Y}$ is the observed variable, $\delta t$ represents a period, $\mathrm{P}$ is the length of $l a g$, and $\varepsilon_{t}$ is the error term. The determination of lag in the data stationarity test employed the Akaike Information Criteria (AIC). To determine which data were stationary and which were non-stationary, it compared the ADF statistical value with the critical value of the statistical distribution $t$. The ADF statistical value is indicated by the value of the statistical t coefficient $\varphi$ Yt-1. If the absolute value of the ADF statistic is higher than the critical value, it suggests that the data are stationary. However, if the opposite occurs, the data are not stationary. 
b. VAR

Vector Auto-Regressive (VAR) applied to capture interdependence on all variables. VAR is a model with more than one dynamic variable (Stock \& Watson, 2001). VAR model also applies lag to each variable used. VAR model in this study is written as follows:

$$
\begin{aligned}
& \Delta I H S G_{t}=\propto_{0}+\sum_{i=1}^{P} \beta_{1 i} \Delta I H S G_{t-1}+\sum_{i=1}^{P} \beta_{2 i} \Delta F R_{t-1}+\sum_{i=1}^{P} \beta_{3 i} \Delta I N F_{t-1}+\sum_{i=1}^{P} \beta_{4 i} \Delta D J I_{t-1}+\sum_{i=1}^{P} \beta_{5 i} \Delta K U R S_{t-1}+\sum_{i=1}^{P} \beta_{6 i} \Delta W T I_{t-1}+\varepsilon_{t} \\
& \Delta F R_{t}=\gamma_{0}+\sum_{i=1}^{P} \gamma_{1 i} \Delta I H S G_{t-1}+\sum_{i=1}^{P} \gamma_{2 i} \Delta F R_{t-1}+\sum_{i=1}^{P} \gamma_{3 i} \Delta I N F_{t-1}+\sum_{i=1}^{P} \gamma_{4 i} \Delta D J I_{t-1}+\sum_{i=1}^{P} \gamma_{5 i} \Delta K U R S_{t-1}+\sum_{i=1}^{P} \gamma_{6 i} \Delta W T I_{t-1}+\varepsilon_{t} \\
& \Delta I N F_{t}=\theta_{0}+\sum_{i=1}^{P} \theta_{1 i} \Delta I H S G_{t-1}+\sum_{i=1}^{P} \theta_{2 i} \Delta F R_{t-1}+\sum_{i=1}^{P} \theta_{3 i} \Delta I N F_{t-1}+\sum_{i=1}^{P} \theta_{4 i} \Delta D J I_{t-1}+\sum_{i=1}^{P} \theta_{5 i} \Delta K U R S_{t-1}+\sum_{i=1}^{P} \theta_{6 i} \Delta W T I_{t-1}+\varepsilon_{t} \\
& \Delta D J I_{t}=\eta_{0}+\sum_{i=1}^{P} \eta_{1 i} \Delta I H S G_{t-1}+\sum_{i=1}^{P} \eta_{2 i} \Delta F R_{t-1}+\sum_{i=1}^{P} \eta_{3 i} \Delta I N F_{t-1}+\sum_{i=1}^{P} \eta_{4 i} \Delta D J I_{t-1}+\sum_{i=1}^{P} \eta_{5 i} \Delta K U R S_{t-1}+\sum_{i=1}^{P} \eta_{6 i} \Delta W T I_{t-1}+\varepsilon_{t} \\
& \Delta K U R S_{t}=\vartheta_{0}+\sum_{i=1}^{P} \vartheta_{1 i} \Delta I H S G_{t-1}+\sum_{i=1}^{P} \vartheta_{2 i} \Delta F R_{t-1}+\sum_{i=1}^{P} \vartheta_{3 i} \Delta I N F_{t-1}+\sum_{i=1}^{P} \vartheta_{4 i} \Delta D J I_{t-1}+\sum_{i=1}^{P} \vartheta_{5 i} \Delta K U R S_{t-1}+\sum_{i=1}^{P} \vartheta_{6 i} \Delta W T I_{t-1}+\varepsilon_{t} \\
& \Delta W T I_{t}=\delta_{0}+\sum_{i=1}^{P} \delta_{1 i} \Delta I H S G_{t-1}+\sum_{i=1}^{P} \delta_{2 i} \Delta F R_{t-1}+\sum_{i=1}^{P} \delta_{3 i} \Delta I N F_{t-1}+\sum_{i=1}^{P} \delta_{4 i} \Delta D J I_{t-1}+\sum_{i=1}^{P} \delta_{5 i} \Delta K U R S_{t-1}+\sum_{i=1}^{P} \delta_{6 i} \Delta W T I_{t-1}+\varepsilon_{t}
\end{aligned}
$$

$\Delta I H S G_{t}$ is a change in the stock index, $\Delta F R_{t}$ are changes in interest rates the Fed, $\Delta I N F_{t}$ is the change in inflation, $\Delta D J I_{t}$ is changes to the stock index in Dow Jones, $\Delta K U R S_{t}$ are changes in the exchange rate of the rupiah against the US dollar, $\Delta W T I_{t}$ is changes in world oil prices, and $\beta, \gamma, \theta, \eta, \vartheta$, and $\delta$ is the parameter vector of each variable.

\section{c. Johansen's cointegration}

Based on Engle and Granger (1987), the existence of non-stationary variables causes the possibility of a long-term relationship between variables in the system. A cointegration test was conducted to determine the presence of relationships between variables, especially in the long run. If there is cointegration of the variables used in the model, it can be ensured that there is a long-term relationship between the variables. The method that could be used in testing the existence of this cointegration was the Johansen Cointegration method (Basuki and Yuliadi, 2015). The formula of Johansen's cointegration is as follows:

$$
\gamma_{t}=v+\sum_{i=1}^{K} \theta_{i} \gamma_{t-1}+\varepsilon_{t}
$$

$\mathrm{Y}$ is one endogenous vector variable, $\mathrm{v}$ is the parameter vector, and $\varepsilon$ is the residual vector. The trace and maximum eigenvalue tests in Johansen's cointegration determine the number of cointegrated vectors. If the probability value of the trace test and the maximum eigenvalue are smaller than alpha, then the model has cointegration.

\section{d. VAR/VECM Empirical Model}

After the cointegration was identified, the next test was carried out using the error correction method. If there were differences in the degree of integration between test variables, the test was carried out jointly between the long-term equations with the error 
correction equation, after the occurrence of the cointegration variable. However, if no cointegration phenomenon was found, then the test was continued using the first difference variable. VECM is a form of VAR that is restricted because of the existence of data forms that are not stationary but cointegrated (Basuki \& Prawoto 2016). VECM is often referred to as a VAR design for non-stationary series that has a cointegration relationship. The VECM specification restricts the long-term relationship of endogenous variables so that they converge into their cointegration relationships, while still providing the existence of short-term dynamics. The VECM model in this study is as follows:

$$
\begin{aligned}
& \Delta I H S G_{t}=\propto_{0}+\sum_{i=1}^{P} \beta_{1 i} \Delta I H S G_{t-1}+\sum_{i=1}^{P} \beta_{2 i} \Delta F R_{t-1} \\
& +\sum_{i=1}^{P} \beta_{3 i} \Delta I N F_{t-1}+\sum_{i=1}^{P} \beta_{4 i} \Delta D J I_{t-1}+\sum_{i=1}^{P} \beta_{5 i} \Delta K U R S_{t-1}+\sum_{i=1}^{P} \beta_{6 i} \Delta W T I_{t-1}+\lambda_{i} Z_{t-1}+\varepsilon_{t} \\
& \Delta F R_{t}=\gamma_{0}+\sum_{i=1}^{P} \gamma_{1 i} \Delta I H S G_{t-1}+\sum_{i=1}^{P} \gamma_{2 i} \Delta F R_{t-1} \\
& +\sum_{i=1}^{P} \gamma_{3 i} \Delta I N F_{t-1}+\sum_{i=1}^{P} \gamma_{4 i} \Delta D J I_{t-1}+\sum_{i=1}^{P} \gamma_{5 i} \Delta K U R S_{t-1}+\sum_{i=1}^{P} \gamma_{6 i} \Delta W T I_{t-1}+\lambda_{i} z_{t-1}+\varepsilon_{t} \\
& \Delta I N F_{t}=\theta_{0}+\sum_{i=1}^{P} \theta_{1 i} \Delta I H S G_{t-1}+\sum_{i=1}^{P} \theta_{2 i} \Delta F R_{t-1} \\
& +\sum_{i=1}^{P} \theta_{3 i} \Delta I N F_{t-1}+\sum_{i=1}^{P} \theta_{4 i} \Delta D J I_{t-1}+\sum_{i=1}^{P} \theta_{5 i} \Delta K U R S_{t-1}+\sum_{i=1}^{P} \theta_{6 i} \Delta W T I_{t-1}+\lambda_{i} Z_{t-1}+\varepsilon_{t} \\
& \Delta D J I_{t}=\eta_{0}+\sum_{i=1}^{P} \eta_{1 i} \Delta I H S G_{t-1}+\sum_{i=1}^{P} \eta_{2 i} \Delta F R_{t-1} \\
& +\sum_{i=1}^{P} \eta_{3 i} \Delta I N F_{t-1}+\sum_{i=1}^{P} \eta_{4 i} \Delta D J I_{t-1}+\sum_{i=1}^{P} \eta_{5 i} \Delta K U R S_{t-1}+\sum_{i=1}^{P} \eta_{6 i} \Delta W T I_{t-1}+\lambda_{i} Z_{t-1}+\varepsilon_{t} \\
& \Delta K U R S_{t}=\vartheta_{0}+\sum_{i=1}^{P} \vartheta_{1 i} \Delta I H S G_{t-1}+\sum_{i=1}^{P} \vartheta_{2 i} \Delta F R_{t-1} \\
& +\sum_{i=1}^{P} \vartheta_{3 i} \Delta I N F_{t-1}+\sum_{i=1}^{P} \vartheta_{4 i} \Delta D J I_{t-1}+\sum_{i=1}^{P} \vartheta_{5 i} \Delta K U R S_{t-1}+\sum_{i=1}^{P} \vartheta_{6 i} \Delta W T I_{t-1}+\lambda_{i} Z_{t-1}+\varepsilon_{t} \\
& \Delta W T I_{t}=\delta_{0}+\sum_{i=1}^{P} \delta_{1 i} \Delta I H S G_{t-1}+\sum_{i=1}^{P} \delta_{2 i} \Delta F R_{t-1} \\
& +\sum_{i=1}^{P} \delta_{3 i} \Delta I N F_{t-1}+\sum_{i=1}^{P} \delta_{4 i} \Delta D J I_{t-1}+\sum_{i=1}^{P} \delta_{5 i} \Delta K U R S_{t-1}+\sum_{i=1}^{P} \delta_{6 i} \Delta W T I_{t-1}+\lambda_{i} Z_{t-1}+\varepsilon_{t}
\end{aligned}
$$

$\Delta I H S G_{t}$ are changes to the stock index, $\Delta F R_{t}$ are changes in interest rates the Fed, $\Delta I N F_{t}$ is the change in inflation, $\Delta D J I_{t}$ is changes to the stock index in Dow Jones, $\Delta K U R S_{t}$ are changes in the exchange rate of the rupiah against the US dollar, $\Delta W T I_{t}$ are changes in world oil prices. All variables use natural logarithms, and formulas " $p$ " indicates that there is a lag on each variable. The coefficient $\lambda$ shows the error correction term value used to calculate the speed of correction in the short run to get its balance in the long run. $\beta, \gamma$, $\theta, \eta, \vartheta$, and $\delta$ is the parameter vectors of each variable.

\section{Result and Discussion}

\section{Stationary Test}

From table 2, it can be seen that in the stationary level test, one of six variables was declared to be qualified, i.e., Inflation (Indonesian Inflation). Meanwhile, the other variables; Log 
Prawoto \& Putra

The Factors Affecting the Composite Stock Price Index (CSPI) of Indonesia Stock Exchange

Table 2 Stationary Test

\begin{tabular}{|c|c|c|c|c|c|c|c|}
\hline \multicolumn{8}{|c|}{ ADF } \\
\hline \multirow[t]{2}{*}{ Variable } & \multicolumn{3}{|c|}{ Level test } & \multirow[t]{2}{*}{ Variable } & \multicolumn{3}{|c|}{ First Difference Test } \\
\hline & $\begin{array}{l}\text { ADF t- } \\
\text { Statistic }\end{array}$ & Prob & Description & & $\begin{array}{c}\text { ADF t- } \\
\text { Statistics }\end{array}$ & Prob & Information \\
\hline Log CSPI & $-0,6131$ & 0,8593 & $\begin{array}{c}\text { Not } \\
\text { stationary }\end{array}$ & Log CSPI & $-6,6083$ & 0,0000 & Stationary \\
\hline $\begin{array}{l}\text { The Fed } \\
\text { Rate }\end{array}$ & 4,00917 & 1,0000 & $\begin{array}{c}\text { Not } \\
\text { stationary }\end{array}$ & $\begin{array}{l}\text { The Fed } \\
\text { Rate }\end{array}$ & $-4,2347$ & 0,0013 & Stationary \\
\hline Inflation & $-5,3901$ & 0,0000 & Stationary & Inflation & $-7,4459$ & 0,0000 & Stationary \\
\hline Log DJI & 0,06046 & 0,9599 & $\begin{array}{c}\text { Not } \\
\text { stationary }\end{array}$ & Log DJI & $-8,4267$ & 0,0000 & Stationary \\
\hline $\begin{array}{l}\text { Log } \\
\text { Exchange } \\
\text { Rate }\end{array}$ & $-2,4653$ & 0,1291 & $\begin{array}{c}\text { Not } \\
\text { stationary }\end{array}$ & $\begin{array}{l}\text { Log } \\
\text { Exchange } \\
\text { Rate }\end{array}$ & $-6,96$ & 0,0000 & Stationary \\
\hline Log WTI & $-1,4297$ & 0,5616 & $\begin{array}{c}\text { Not } \\
\text { stationary }\end{array}$ & Log WTI & $-5,683$ & 0,0000 & Stationary \\
\hline
\end{tabular}

CSPI (Composite Stock Price Index), The Fed Rate (Interest Rate of the Fed), Log DJI (Dow Jones Industrial Average), Log Exchange Rate (value rupiah exchange rate against the dollar), and the Log WTI (World oil prices based on West Texas Intermediate) did not pass the stationary level test. Furthermore, in the first difference level test, all variables were declared to pass with a level of $\alpha=5 \%$.

\section{Cointegration Test}

Cointegration testing aims to determine the long-term relationship of each variable. It is due to the requirements of the VECM estimation, namely therein lies cointegration relationship. If there is no cointegration relationship, then the VECM estimate cannot be used. Therefore, the Vector Auto Regression (VAR) model should be applied. This research used Johansen's Cointegration Test with a critical value of 0.05 .

Based on table 3, it can be seen that at the test level of 5 percent (0.05), six rank variables had a cointegration relationship. The data could be proven from each of the Trace Statistics values of 145.6499, 90.66088, 52.65460, 31.01241, 16.41913, and 4.932569, which were higher than the Critical Value of 0.05 , namely 95.75366, 69.81889, 47.85613, $29.79707,15.49471$, and 3.841466 . Thus, the variables used in this study had a long-term relationship (cointegration) between one another.

Table 3 Cointegration Test Results (Johansen's Cointegration Test) Unrestricted Cointegration Rank Test (Trace)

\begin{tabular}{lcccc}
\hline Hypothesized No. of CE(s) & Eigenvalue & Trace & $\mathbf{0 . 0 5}$ Critical & Prob.** \\
& & Statistic & Value & \\
\hline None* & 0.618910 & 1.456 .499 & 9.575 .366 & 0.0000 \\
At most 1* & 0.434294 & 9.066 .088 & 6.981 .889 & 0.0005 \\
At most 2* & 0.259616 & 5.265 .460 & 4.785 .613 & 0.0166 \\
At most 3* & 0.183464 & 3.101 .241 & 2.979 .707 & 0.0361 \\
At most 4* & 0.152956 & 1.641 .913 & 1.549 .471 & 0.0362 \\
At most 5* & 0.050765 & 4.932 .569 & 3.841 .466 & 0.0263 \\
\hline
\end{tabular}


Prawoto \& Putra

The Factors Affecting the Composite Stock Price Index (CSPI) of Indonesia Stock Exchange

The Interpretation of VECM (Vector Error Correction Model) Estimation Results

Table 4 Short-Term VECM (Vector Error Correction Model) Estimation Results

\begin{tabular}{lcc}
\hline \multicolumn{1}{c}{ Variable } & Coefficient & Partial t-Statistic \\
\hline CointEq1 & -0.546243 & {$[-3.23736]$} \\
D(LOGCSPI(-1)) & 0.466967 & {$[2.17867]$} \\
D(LOGCSPI (-2)) & 0.673224 & {$[3.14910]$} \\
$D($ INF(-1)) & -0.028981 & {$[-2.07283]$} \\
D(INF(-2)) & -0.028972 & {$[-2.73010]$} \\
D(INF(-3)) & -0.038403 & {$[-4.44411]$} \\
D(LOGEXCHANGERATE(-2)) & 0.883197 & {$[2.71356]$} \\
D(LOGWTI(-2)) & 0.107044 & {$[1.96606]$} \\
\hline
\end{tabular}

After conducting various pre-estimation test stages, VECM estimation would be suitable for our analysis to identify the short-term relationship and the long-term effect of the independent variables on the dependent variable.

Table 4 shows the short-term variables that affected the movement of the CSPI in the short term. The LOG CSPI had a significant effect on lag 1 and lag 2, and then three independent variables had a significant impact on the LOG CSPI. The three independent variables were INF $(-1,-2,-3)$, LOG EXCHANGE RATE (-2), and LOG WTI (-2). Short-term estimation results showed that the LOG CSPI variable in lag 1 and lag 2 had a positive effect and significant to the LOG CSPI itself, i.e., 0.466 and 0.673. It means that if there were an increase in the LOG CSPI in lag 1, it would increase the LOG CSPI by 0.466 percent. Also, if there were an increase in the LOG CSPI in lag 2, it would increase the LOG CSPI by 0.673 percent. Short-term estimation results indicated that the INFLATION variable at lag 1 , lag 2, and lag 3 had a negative effect on the LOG CSPI, which was $-2,072,-2.73$, and 4.44. It means that if there were an increase in Inflation in lag 1 , it would decrease the LOG CSPI by -0.0289 percent. If there were an increase in Inflation in lag 2 , it would decrease the LOG CSPI by -0.0289 percent. Then, if there were an increase in Inflation in lag 3 , it would reduce the LOG CSPI by -0.0384 percent.

The short-term estimation results showed that the LOG Exchange Rate variable in lag 2 had a positive effect on the LOG CSPI, which was 0.883 . Thus, if there were an increase in the LOG Exchange Rate in leg 2, it would increase the LOG CSPI by 0.883 percent. The short-term estimation results showed that the LOG WTI variable in lag 2 had a positive effect on the LOG CSPI, which was equal to 0.107 . Therefore, if there were an increase in the LOG WTI in leg 2 , it would increase the LOG CSPI by 0.107 percent.

In the regression results, it is known that Fed Rate did not affect the movement of the CSPI in the short run. It was because of a quick response from the government in tackling the movement of the Fed by raising interest rates or the BI Rate; then, the market tended to ignore the movement of the Fed. Based on regression results, the effect of Inflation on the CSPI in the short term was driven by an increase in production costs, which resulted in a decrease in company profits. The decline in corporate profits caused a decline in share prices and CSPI. This result supports the research of Mohammad and Ullah (2017), which 
stated that inflation had a significant negative effect on the movement of the Composite Stock Price Index.

In the regression results, it is known that the Dow Jones Index did not affect the movement of the CSPI in the short term. Research data showed that in the short term, the index was stable so that the movement of the Dow Jones Index did not significantly affect the CSPI. Thus, the short-term movement of the Dow Jones Index did not affect the CSPI. In the regression results, it is identified that there was a short-term effect of the exchange rate on CSPI. This effect was driven by the nominal of Rupiah (depreciation), which caused the value of goods in Indonesia to be relatively cheaper. Therefore, an increase in demand for export goods by foreigners resulted in increased profits for exporting companies. Then, it could increase stock prices and increased CSPI, which is in line with the results of the study indicated by Handiani's research (2014). The following regression results are known that there was an influence of World Oil Prices on CSPI in the short term; it was driven by an increase in world oil prices resulting in increasing profits of mining companies, especially oil. It resulted in an increase in the company's stock price and could cause an increase in the Jakarta Composite Index. The same thing was also stated in a study conducted by Kilian and Park (2009) and Witjaksono (2017), which showed that world oil prices had a positive effect on the movement of the Composite Stock Price Index. Besides, the error correction term (ECT) value showed significant results with a coefficient of -0.5462 , which indicated that if an error occurs in the short term, it would be corrected by 1.83 months to get into equilibrium in the longterm stage.

Based on table 5, the FR variable in lag 1 had a negative and significant effect on the CSPI LOG, i.e., 0.284. Thus, if there were an increase in FR of one percent in the previous year, then the CSPI LOG would decrease by 0.284 percent. The analysis showed that the partial $t$-statistic value of the FR variable at lag 1 was -9.37092 (probability t count $<0.05$ ). The data indicate that $\mathrm{H}_{0}$ was rejected, and $\mathrm{H}_{1}$ was accepted. In other words, the FR variable significantly affected the LOG CSPI in the long-term. The long-term VECM estimation results showed that the INF variable at lag 1 had a negative and significant effect on the LOG CSPI, which as equal to 0.099 . Therefore, if the INF variable increased one percent in the previous year, it would reduce the CSPI LOG by 0.099 percent. The analysis showed that the partial t-statistic value of the INF variable at lag 1 was -6.01471 (probability $t$ count $<0.05$ ), which means that $\mathrm{H}_{0}$ was rejected, and $\mathrm{H}_{1}$ was accepted. In other words, the INF variable had a significant effect on the CSPI LOG in the long-term stage.

Table 5 Long-Term VECM (Vector Error Correction Model) Estimation Results

\begin{tabular}{|c|c|c|}
\hline Variable & Coefficient & Partial t-statistic \\
\hline FR(-1) & -0.284439 & {$[-9.37092]$} \\
\hline INF(-1) & -0.099915 & {$[-6.01471]$} \\
\hline LOGDJI(-1) & -1.791 .351 & [18.1002] \\
\hline LOGEXCHANERATE(-1) & 1.252 .540 & [12.3100] \\
\hline LOGWTI(-1) & 0.163721 & [8.88848] \\
\hline
\end{tabular}


Long-term VECM estimation results showed that the LOG DJl variable in lag 1 had a negative and significant effect on LOG CSPI, i.e., 1.791. Thus, if DJI LOG increased one percent in the previous year, it would reduce the LOG CSPI by 1.791 percent. The analysis showed that the partial t-statistic value of the LOG DJI variable at lag 1 was -18.1002 (probability t count $<0.05$ ). These data indicate that $\mathrm{H}_{0}$ was rejected, and $\mathrm{H}_{1}$ was accepted. In other words, the LOG DJI variable significantly affected the LOG CSPI in the long-term. Long-term VECM estimation results showed the LOG Exchange Rate variable in lag 1 had a positive and significant effect on the LOG CSPI, i.e., 1,252. Thus, if LOG Exchange Rate increased one percent in the previous year, then the LOG CSPI would increase by 1,252 percent. The analysis showed that the partial t-statistic value of the LOG Exchange Rate variable at lag 1 was 12.3100 (probability t count $<0.05$ ). These data indicate that $\mathrm{H}_{0}$ was rejected, and $\mathrm{H}_{1}$ was accepted. In other words, the LOG Exchange Rate variable significantly influenced the long-term LOG CSPI. The long term VECM estimation results showed that the LOG WTI variable in lag 1 had a positive and significant effect on the LOG CSPI, which was equal to 0.163 . Hence, if the LOG WTI increased one percent in the previous year, it would increase the LOG CSPI by 0.163 percent. The analysis showed that the partial t-statistic value of the LOG WTI variable at lag 1 was 8.88848 (probability $t$ count $<0.05$ ). It means $\mathrm{H}_{0}$ was rejected, and $\mathrm{H}_{1}$ was accepted. In other words, the LOG WTI variable significantly influenced the LOG CSPI in the long term.

Furthermore, Long-term VECM estimation results showed that Fed Rate had a long term and significant negative effect on the CSPI fluctuation. The results of the analysis, which stated that the Fed Rate had a negative effect on the CSPI, is in line with what was stated in Gom's research (2015). It showed that the FR had a negative impact on the movement of the Composite Stock Price Index. The Dow Jones Index variable, in the long term, had a negative impact on the CSPI. It showed that the Dow Jones index and CSPI had the opposite direction in the study period

The Impulse Response Function (IRF)

IRF analysis showed the response of the CSPI when the Fed Rate experienced a shock. As a result, the CSPI response became negative from the 2 nd to the 10th periods, even though in the 6th period, it declined from the negative reaction. This data explains that when interest rates from the Fed experience a shock, the opposite movement, or a negative response to the CSPI takes place. This response is caused by the existence of capital outflows or foreign funds coming out of the capital market so that an investor will choose to invest in more profitable instruments.

IRF analysis showed the response of the CSPI at the time of inflation experienced a shock, resulting in the CSPI response became negative from the 1st to the 10th periods. This analysis explains that when shocks occur in inflation, movement in the opposite direction or a negative response to the CSPI occurs. This negative response may occur because inflation causes price increases and causes increased production costs in a company. Also, it can affect the decline in company profits resulting in a decrease in the stock price of the company. 


\section{Prawoto \& Putra}

The Factors Affecting the Composite Stock Price Index (CSPI) of Indonesia Stock Exchange

IRF analysis showed the CSPI response when the Dow Jones Index experienced a shock. The positive response resulted in the CSPI response from the first to the tenth periods, even though in the sixth period, it experienced a small negative response. The response was positive because it was still above the horizontal line. This analysis explains that when the Dow Jones Index experiences a shock, the same movement or positive response to the CSPI occurs. This response occurs following the theory of economic integration in the financial markets, which can lead to a relationship between economic variables among countries. As a result, the variables that affect the CSPI need to be known by the investors; then, investors can make the right decision.

IRF analysis showed the response of the CSPI when the exchange rate was in shock. When the exchange rate was in shock, the CSPI response became positive from the first to the tenth periods, even though the fourth period experienced a small negative response. This response was quite positive because it was still above the horizontal line. The previous explanation describes that when the exchange rate experiences a shock, there will be a positive impact on the CSPI. This response occurs because the exchange rate can affect demand from abroad. This influence can cause an increase in exports in Indonesia and generate higher profits for companies that export.

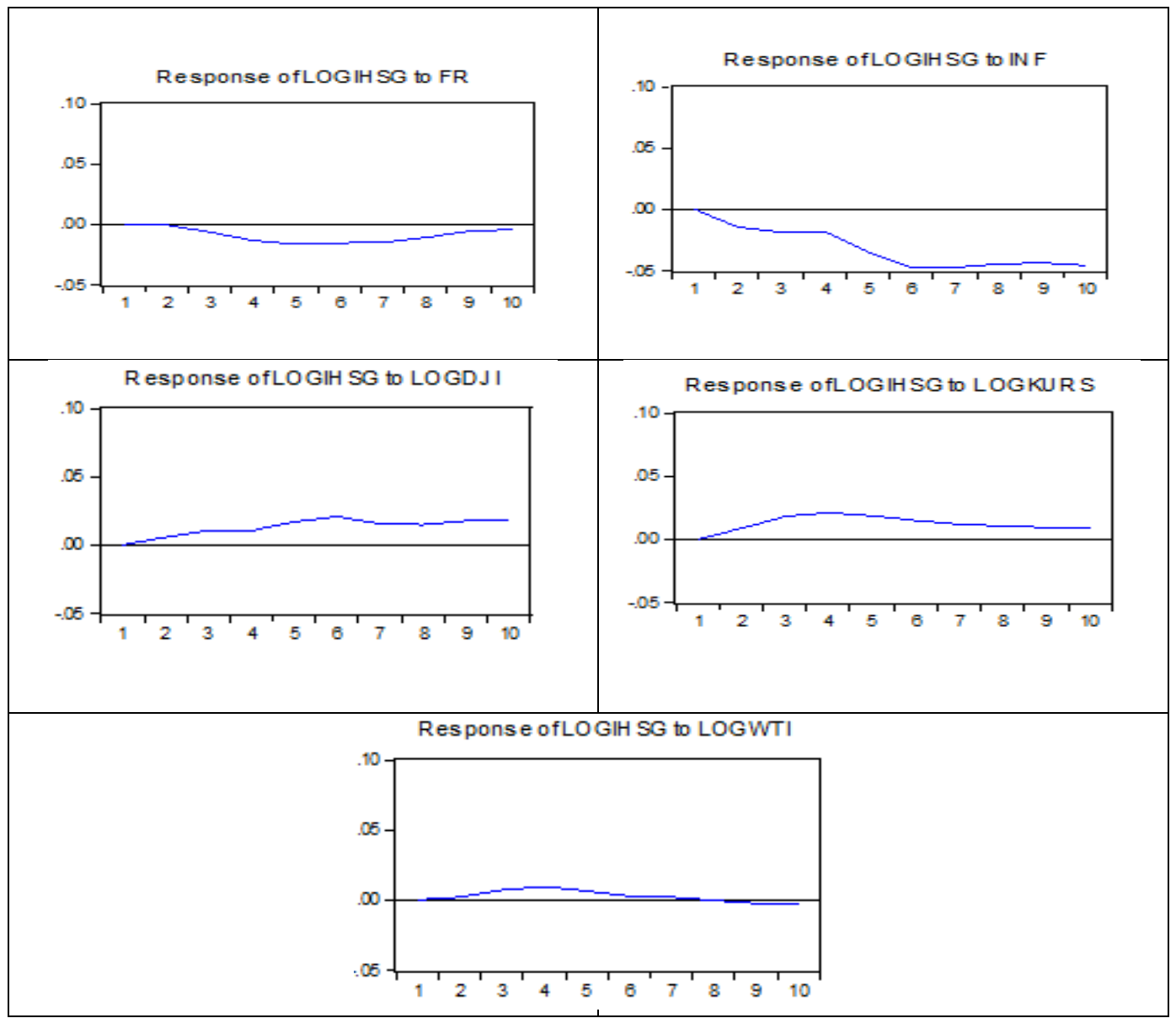

Figure 2 Impulse Response Function 
IRF analysis showed the response of the CSPI at a time when world oil prices were in shock. When the world oil experienced a shock, the CSPI response became neutral in the first period but was classified as positive until the seventh period. However, in the 8th period, it experienced a small negative response until the tenth period. In a short period, world oil prices did not significantly affect the CSPI. The information mentioned before explains that when world oil prices experience a shock, the same movement or a positive impact on the CSPI occurs. This response indicates that when world oil prices experience a shock, it will have an effect on industries that are still mostly using oil as their energy, and this will affect the CSPI in Indonesia.

The VD (Variance Decomposition) Analysis Results

The results of the VD (figure 6) indicate that the Fed Rate variable had a contribution of only up to $2.69 \%$ in explaining the CSPI variable. The results of VD suggest that the inflation variable had a contribution of only up to $3.53 \%$ in explaining the CSPI variable. The results of the VD showed that the Dow Jones Index variable contributed only up to $24.04 \%$ in explaining the CSPI variable. The significant contribution or influence of the Dow Jones Index variable would be better able to define the CSPI variable than other variables. The results of VD showed that the exchange rate variable had a contribution of only up to $0.30 \%$ in explaining the CSPI variable. The results of VD indicate that the world oil prices had a contribution of only up to $0.71 \%$ in explaining the CSPI variable.

Table 6 Varian Decomposition of LOG CSPI

\begin{tabular}{cccccccc}
\hline Period & S.E & LOG CSPI & FR & INF & LOG DJI & $\begin{array}{c}\text { LOG } \\
\text { EXCHANG } \\
\text { E RATE }\end{array}$ & LOG WTI \\
\hline 1 & 0.028093 & 100.0000 & 0.000000 & 0.000000 & 0.000000 & 0.000000 & 0.000000 \\
2 & 0.046658 & 92.20222 & 0.487584 & 2.018182 & 4.271592 & 0.301887 & 0.718537 \\
3 & 0.067927 & 87.30924 & 0.453460 & 3.535437 & 8.198837 & 0.163590 & 0.339434 \\
4 & 0.086232 & 83.20022 & 0.303571 & 2.474309 & 13.70331 & 0.101512 & 0.217080 \\
5 & 0.100959 & 78.88783 & 0.231802 & 2.039119 & 18.33681 & 0.205729 & 0.298716 \\
6 & 0.114253 & 76.07897 & 0.351427 & 1.640364 & 21.39912 & 0.186251 & 0.343874 \\
7 & 0.124641 & 74.67334 & 1.069748 & 1.678403 & 22.12014 & 0.167093 & 0.291282 \\
8 & 0.133428 & 73.47225 & 1.566907 & 1.685485 & 22.86732 & 0.148221 & 0.259822 \\
9 & 0.141561 & 72.46852 & 2.108883 & 1.506259 & 23.53405 & 0.133392 & 0.248893 \\
10 & 0.149162 & 71.49669 & 2.690845 & 1.374609 & 24.04708 & 0.120208 & 0.270571 \\
\hline
\end{tabular}

\section{Conclusion}

The results of the regression analysis note that the influence of the Fed Rate on the CSPI in the short term had no effect on the movement of the CSPI, whereas, in the long term, the Fed Rate had a significant negative effect on the CSPI movement. It indicates that the influence of the Fed Rate variable was a change in behavior, which at first, it was insignificant in the short run, but in the long run, it became significant. It showed the response of The Fed Rate variable on CSPI tended to be slow. The results of the analysis of the effect of inflation on the CSPI in the short and long term had a negative effect. It indicates that the influence of the inflation variable did not change behavior, both short- 
term and long-term, and its effect is consistent with the theory that inflation had a negative effect on the industry. Regression results were known that the results of the analysis of the influence of the Dow Jones Index on the CSPI in the short term had no effect on the movement of the CSPI, while in the long run, the Dow Jones Index had a negative effect on the CSPI. It indicates that the influence of the Dow Jones index was changing behavior in the short and long term.

The results of the analysis of the influence of Exchange Rate on CSPI in the short and long term had a positive effect. It indicates that the effect of Exchange Rate was consistent, both in the short and long term, to changes in the CSPI and showed that the short-term and long-term response remained positive that when the depreciation of the Rupiah pushed exports and increased industry. The regression results of the influence of World Oil Prices on the CSPI in the short and long term had a positive effect. It indicates that the effect of world oil prices was consistent, both in the short and long term, to changes in the CSPI and showed that the industry responded quickly when there were changes in oil prices. In the five independent variables, inflation, exchange rates, and world oil prices had a rapid influence on the CSPI. Whereas, the Fed Rate and Dow Jones Index variables were slow and long-term effects. However, seen from the analysis of Variance Decomposition, the biggest contribution that could explain the dependent variable was the Dow Jones index variable and inflation.

\section{Suggestion}

The results showed that the CSPI movement was influenced by internal factors (inflation and exchange rates) and also influenced by external factors (The Fed Rate, Dow Jones Index, and World Oil Prices). In this case, of course, the Government must be consistent in maintaining the stability of the value of inflation and exchange rates. In addition, the government must be able to anticipate the influence of external factors, such as the Fed Rate, Dow Jones Index, and World Oil Prices. The anticipation that must be done is to adjust the $\mathrm{BI}$ rate, fiscal incentives, and policies to reduce the high-cost economy through the bureaucracy. Then, investors are advised to understand the changes in internal and external factors that can affect their companies. The anticipation of investors remains loyal to serve consumers and create optimization of production so that their companies remain efficient. On the other hand, investors should not panic, such as short-term stock sales in the face of changes in variables that affect the industry.

\section{References}

Basuki, A. T \& Prawoto, N (2016). Analisis Regresi dalam Penelitian Ekonomi \& Bisnis. Jakarta: PT. Raja Grafindo Persada

Basuki, A. T \& Yuliadi, I. (2015). Ekonometrika Teori \& Aplikasi. Yogyakarta: Mitra Pustaka Nurani.

Bhuiyan, M, E., \& Chowdhury, M. (2019). Macroeconomic variables and stock market indices: Asymmetric dynamics in the US and Canada. Quarterly Review of Economics and Finance, 1-37. https://doi.org/10.1016/j.qref.2019.10.005 
Campbell, J. Y., \& Ammer, J. (1993). What moves the stock and bond markets? A variance decomposition for long-term asset returns. Journal of Finance, XLVIII, 3-37. https://doi.org/10.1111/j.1540-6261.1993.tb04700.x

Campbell, J. Y., \& Shiller, R.J. (1988). The dividend-price ratio and expectations of future dividends and discount factors. Review of Financial Studies, 1(3), 195-228. https:// doi.org/10.1093/rfs/1.3.195

Engle, R.F., \& Granger, C.W.J. (1987). Cointegration and error correction: representation, estimation, and testing. Econometrica, 55(2), 251-276. https://doi.org/10.2307/1913236

Fama, E. F. (1970). Efficient Market: A Review of Theory and Empirical Work. Journal of Finance, 25(2) 383-417. https:// doi.org/10.2307/2325486

Gom, H. G. (2015). Analisis Pengaruh the Fed Rate, Indeks Dow Jones Dan Indeks Nikkei225 Terhadap Indeks Harga Saham Gabungan (IHSG) di Bursa Efek Indonesia (BEI) Periode 2008-2013. Jurnal Ekonomi dan Keuangan, 1(8). Received from https://media.neliti.com/media/publications/14754-ID-analisis-pengaruh-the-fedrate-indeks-dow-jones-dan-indeks-nikkei225-terhadap-in.pdf

Handiani, S. (2014). Pengaruh Harga Emas Dunia, Harga Minyak Dunia dan Nilai Tukar Dolar Amerika/Rupiah Terhadap Indeks Harga Saham Gabungan Pada Periode 20082013. E-Journal Graduate Unpar, 1(1), 85-93. Received from http://journal.unpar.ac.id/index.php/unpargraduate/article/view/552

Humpe, A., \& Macmillan, P. (2009). Can macroeconomic variables explain long-term stock market movements? A comparison of the US and Japan. Applied Financial Economics, 19(2), 111 - 119. https://doi.org/10.1080/09603100701748956

Kilian, L., \& Park, C. (2009). The impact of oil price shocks on the US stock market. International Economic Review, 50(4), 1267-1287. https://doi.org/10.1111/j.14682354.2009.00568.x

Markowitz, H. (1952). Portfolio Selection. The Joumal of American Finance, 7(1), 77-91. https://doi.org/10.1111/j.1540-6261.1952.tb01525.x

Mohammad, G., \& Ullah, W. (2017). Effect of Macroeconomic Variables on Stock Market Performance of SAARC Countries. Asian Economic and Financial Review, 7(8), 770-779. https://doi.org/10.18488/journal.aefr.2017.78.770.779

Nasseh, A., \& Strauss, J. (2000). Stock prices and domestic and international macroeconomic activity: a Cointegration approach. Quarterly Review of Economics and Finance, 40(2), 229245. https://doi.org/10.1016/s1062-9769(99)00054-x

Ratanapakorn, O., \& Sharma, S. C. (2007). Dynamic analysis between the US stock returns and the macroeconomic variables. Applied Financial Economics, 17(5), 369-377. https://doi.org/10.1080/09603100600638944

Ross, S, A. (1976). The arbitrage theory of capital asset pricing. Journal of Economic Theory, 13, 341 - 360. https://doi.org/10.1016/0022-0531(76)90046-6

Samsul, M. (2015). Pasar Modal \& Manajemen Porfolio. Jakarta: Erlangga.

Stock, J, H., \& Watson, M, W. (2001). Vector Autoregression. Journal of Economic Perspectives, 15(4), 101 -116. https://doi.org/10.1257/jep.15.4.101

Witjaksono, A. A. (2010). Analisis Pengaruh Tingkat Suku Bunga SBI, Harga Minyak Dunia, Harga Emas Dunia, Kurs Rupiah, Indeks Nikkei 225, dan Indeks Dow Jones terhadap IHSG (Studi kasus pada IHSG di BEI selama periode 20002009). Doctoral dissertation, Universitas Diponegoro. Received from http://eprints.undip.ac.id/24025/ 